\section{Las clases trabajadoras se movilizan. Antirreeleccionismo e hispanofobia en la ciudad de México, 1892}

Florencia Gutiérrez
Florencia Gutiérrez es Becaria del CONICET con sede en el Instituto Superior de Estudios Sociales de la Universidad Nacional de Tucumán. San Lorenzo 429, (4000) San Miguel de Tucumán, Argentina. e-mail: florenciagutierrezb@yahoo.com

\section{Resumen}

A mediados de 1892, la ciudad de México fue sacudida por una intensa corriente de participación popular que expresó públicamente su disconformidad por la tercera reelección presidencial de Porfirio Díaz. Los promotores de esta movilización pública fueron un grupo de estudiantes y periodistas independientes, quienes pronto contaron con el apoyo de un importante segmento de los trabajadores urbanos.

El propósito de este artículo es estudiar la participación de los artesanos y obreros capitalinos en la conformación y desarrollo de este movimiento opositor a la continuidad de Díaz en el poder. Se trata de analizar las motivaciones por las cuales estos actores decidieron sumarse a la protesta política; evaluar su capacidad de iniciativa, así como sus niveles de organización y reclutamiento; examinar la manera en la que se apropiaron de los discursos liberales y, finalmente, explorar las razones que llevaron a la disolución del movimiento antirreeleccionista. Asimismo, expondremos la capitalización que las clases trabajadoras hicieron de esta coyuntura de movilización.
Este artículo recupera preocupaciones analizadas en la tesis doctoral de la autora, El mundo del trabajo y el poder político. Integración, consenso y resistencia en la ciudad de México a fines del siglo XIX, dirigida por la Dra. Clara E. Lida en El Colegio de México. La autora agradece sus comentarios, así como las sugerencias de Ariel Rodríguez Kuri, Rosalina Ríos Zúñiga, Elisa Speckman y Sonia Pérez Toledo.

\section{Summary}

In the middle of 1892 in México City there was a public outcry against the third presidential re-election of Porfirio Díaz. The promoters of this public demonstration were a group of students and independent journalists who suddenly found support in an important number of urban workers.

The purpose of this article is to study the participation of craftsmen and workers of the capital in the formation and development of this movement that opposed to the continuity of Díaz in power. In fact, it tries to analyse the motivations that lead them to join this political protest; to evaluate their capacity to take the initiative as well as their levels of organization and recruitment; to examine the way in which they took possession of the liberal speeches and finally, to explore the reasons that lead to the dissolution of the anti-re-elections movement. As well as this, it shows how the working classes capitalized this mobilization joint. 